\title{
Taxation of Swedish Firm Owners: The Great Reversal from the 1970s to the 2010s*
}

DOI 10.1515/ntaxj-2017-0002

Received Feb 03, 2017; accepted Mar 31, 2017

\begin{abstract}
By the late 1960s, real effective taxation of income from individual firm ownership in Sweden approached 100 percent. A series of tax reforms has reversed this situation. This paper (1) elucidates the thinking behind the vision of creating a largely market-based system without wealthy capitalists and how that vision guided tax policy; (2) outlines and evaluates the changes in the tax code since the late 1970s, their empirical and intellectual basis, and their implications for the taxation of individual firm ownership; and (3) compares the size of the largest individual wealth holdings in the mid-1960s to their equivalents in the 2010s and discusses how the general public's views have changed regarding sizeable income streams and wealth from business activity. Today, the tax code favors already wealthy individuals, while high labor income taxation combined with a high valuation of existing assets renders wealth accumulation difficult for persons with no initial wealth.
\end{abstract}

Keywords: Owner-level taxation; Entrepreneurship; Institutions; Sweden; Tax policy

JEL-codes: H2O; H32; L26; N44

\section{Introduction}

Regardless of the source of finance, taxation on returns to individuals associated with firm ownership (referred to herein as "individual firm ownership") was very low in

\footnotetext{
Magnus Henrekson: Research Institute of Industrial Economics (IFN), P.O. Box 55665, SE-102 15, Stockholm Sweden; Email: magnus.henrekson@ifn.se; Tel.: +46-8-665 4502

* I thank Niklas Elert, Sven-Olof Lodin, Sven-Ivan Sundqvist, Birgitta Swedenborg, Daniel Waldenström, Simon Ek, and two anonymous reviewers for useful comments and suggestions. Financial support from the Jan Wallander and Tom Hedelius Foundation and from the Marianne and Marcus Wallenberg Foundation is gratefully acknowledged.
}

Sweden until the beginning of World War I. Prior to 1900, the tax rate on returns to firm ownership never exceeded 3 percent, even for high incomes (Johansson et al. (2015)). During World War I, the taxation of individual firm ownership began to rise significantly, and by the early 1950s, real effective taxation of dividend payments was approaching 100 percent even for persons with only moderate annual incomes.

This gradual shift in how business income was taxed fell in line with international trends toward higher effective taxation in general and of capital income in particular. It also fell in line with the goals of the ruling SocialDemocratic government, which sought to achieve a highly equalized income and wealth distribution-to create what has been aptly characterized as "capitalism without capitalists” (Johansson and Magnusson (1998, p. 121)).

The first purpose of this article is to explicate the thinking and rationale behind the vision of creating a largely market-based system without wealthy capitalists, to analyze whether the tax system was in fact designed in line with this vision, and to investigate whether the desired effects have materialized.

The end of the 1970s witnessed a marked change in the international view of the state, on one hand, and private markets, on the other hand. Moreover, the dynamism and innovativeness of the large corporations declined, and it became progressively more obvious that both the increasing dominance of large corporations and its mirror imagethe marginalization of new and small firms-had ground to a halt. There was a renaissance of entrepreneurship and the individual entrepreneur, which was reinforced by a wave of tax reforms that swept the Organization for Economic Co-operation and Development (OECD), beginning with the United States in the first half of the 1980s. Sweden joined this wave. In particular, the 1990/1991 tax reform drastically reduced the tax rates on income derived from individual firm ownership, but several important tax changes were also implemented before "the tax reform of 
the century.” Moreover, there have been numerous other changes to the tax code since 1991 as well. ${ }^{1}$

The second purpose of this article is to outline and evaluate these changes, to assess their empirical and intellectual bases, and to explore their implications for the taxation of individual firm ownership. To illustrate the drastic changes made to Sweden's taxation of individual firm ownership, the effects of current tax rules for a typical ownership case in the 2010s will be contrasted with the effects of the tax rules that applied four decades earlier.

Certain instances of corporate wealth owned and controlled by individuals or families led to considerable political controversy in the 1960s and early 1970s, which contributed to the political support for harsh taxation of individual firm ownership. But how wealthy were the wealthiest persons in the 1960s compared to the wealthiest persons in the 2010s? The final purpose of this article is to compare the size of the largest individual wealth holdings in the mid-1960s to their contemporary equivalents and to discuss in what sense and to what extent the general public's views have changed regarding large individual income streams and substantial wealth derived from business activity.

\section{The Taxation of Entrepreneurship and Business Ownership}

In this section, I will document the most important differences in the effective taxation of the returns on business activity based on the source of finance and type of owner. This includes a discussion of the most important changes in the taxation of various combinations of sources of finance and type of owner from 1970 through the early 2000s. I will illuminate how the taxation of business activity-which includes taxation at both the firm and owner level-is likely to impact the ownership and financing of firms and how the real rate of effective taxation is influenced by who owns the firm and how it is financed. To do so exhaustively, the following taxes on business must be considered:

- Corporate tax: This tax is levied at the firm level as opposed to the owner level.

- Owner-level taxes: The two main owner-level taxes are dividend taxes and capital gains taxes. A third

1 In a survey published in 2010, the Swedish National Audit Office (2010) found that there had been 509 changes in the tax code in 19922009. type is taxation on interest income derived from lending by owners to their own firms. In Sweden, business owners have often been subject to a wealth tax on their ownership shares and gift and inheritance tax has often been levied in connection with generational transfers.

- Income taxes on business owners: In many countries, self-employment income and sole proprietors are taxed as a type of labor income. ${ }^{2}$

Table 1 presents the effective marginal tax rates for different combinations of owners (households, tax-exempt institutions, and insurance companies) and sources of finance (debt, new share issues, and retained earnings) in both 1970 and 1980. The effective marginal tax rates are calculated by assuming a pre-tax real rate of return of 10 percent. A negative number means that the real rate of return is greater after tax than before tax. The table illustrates four key aspects of the Swedish tax system from 1970 to 1980:

1. By and large, debt financing received the most favorable and new share issues the least favorable tax treatment. More than 100 percent of the real rate of return was taxed away for a household buying newly issued shares.

2. Retained earnings were taxed at lower real rates than capital raised through new share issues for households, a scheme that benefitted incumbent firms more than newly established firms. ${ }^{3}$

3. Households were taxed at much higher rates than other owner categories. Moreover, household taxation increased during the 1970s (except for retained

2 The analysis in this article only addresses the case in which ownership consists of shares of a corporation.

3 The reason why effective taxation was so low for retained earnings as the source of finance was due to various accounting measures and tax allowances that applied to retained earnings. The application of these measures enabled firms to sharply reduce the statutory corporate tax rate; large industrial firms frequently managed to reduce the effective corporate tax rate to negligible levels. See Södersten (1984), Norrman and McLure (1997) and Du Rietz et al. (2015) for further details. 
Table 1: Effective marginal tax rates for different combinations of owners and sources of finance in 1970 and 1980 (10 percent real pre-tax rate of return at actual inflation rates).

\begin{tabular}{lccc}
\hline & Debt & New share issues & Retained earnings \\
\hline $\mathbf{1 9 7 0}$ & & & \\
Households & 51.3 & 122.1 & 57.1 \\
Tax-exempt institutions & -64.8 & 15.9 & 32.7 \\
Insurance companies & -45.1 & 42.4 & 41.2
\end{tabular}

\section{0}

Households

Tax-exempt institutions

Insurance companies
58.2

$-83.4$

$-54.9$
136.6
-11.6
38.4

51.9

11.2

28.7

Note: All calculations are based on the actual asset composition in manufacturing. The following inflation rates were used: 7 percent for 1970 and 9.4 percent for 1980. The calculations conform to the general framework developed by King and Fullerton (1984). The average holding period is assumed to be 10 years. A negative tax rate implies that the rate of return after tax is greater than before tax. For instance, a tax rate of -83 percent for a debt-financed investment owned by a tax-exempt institution in 1980 implies that a real rate of return of 10 percent before tax becomes 18.3 percent after tax.

Source: Södersten (1984).

earnings), whereas the reverse occurred for insurance companies and tax-exempt institutions. ${ }^{4}$

4. Tax-exempt institutions enjoyed a substantial tax advantage relative to the other two owner categories, and this advantage was extended during the 1970s.

Fully understanding the magnitude of the effective taxation of individual firm ownership relative to institutional owners might be easier if the analysis were more concrete. Thus, in 1980, a 10 percent real rate of return on an investment financed through a new share issue to a household resulted in an after-tax real rate of return of -3.7 percent; the same investment financed by a debt instrument issued to a tax-exempt institution translated into an 18.3 percent after-tax real rate of return. If the same investment were financed through new shares issued to a tax-exempt institution, it resulted in an after-tax real rate of return of 11.2 percent.

In practice, this scheme meant that the tax system was extremely favorable for existing firms that chose to reinvest their profits in their current operations and for companies in construction and real estate that could operate with very high debt-to-equity ratios. The Swedish tax rules

4 By definition, tax-exempt institutions pay no tax on interest receipts, dividends, or capital gains. This category includes the government at the central, regional, and local level; charities; scientific and cultural foundations; foundations for employee recreation set up by companies; pension funds for supplementary occupational pension schemes; and the National Pension Funds (the AP Funds). For an exhaustive definition, the reader is referred to chapter 7 in the Income Tax Act (1999:1229). also became increasingly favorable toward investments in machinery and buildings (Södersten (1984)) while failing to incentivize individual risk-taking and efficient corporate governance. Existing firms were increasingly understood as "sort of God-given national endowments, like inexhaustible oil wells” (Bergman et al. (1998, p. 30)).

The first significant reforms of the Swedish tax system are normally said to be the result of "the wonderful night" in 1981. However, with regard to the taxation of business ownership, reducing the tax-assessed value of individually owned (unlisted) corporate wealth to 30 percent of net book value in 1978 considerably alleviated the wealth and inheritance tax previously levied on business owners.

A wave of tax reforms swept across the OECD countries during the 1980s, resulting in lower tax rates and broader tax bases. ${ }^{5}$ The Swedish "tax reform of the century" was fully implemented in 1991 (Agell et al. (1995)). The top marginal tax rate on labor income was set at 50 percent, down from 80 percent just a few years earlier. The capital income tax rate was lowered to 30 percent, which was a dramatic drop, as current capital income had previously been taxed at the same rate as labor income, that is, typically $75-80$ percent. Likewise, the corporate tax rate was lowered from 52 percent (in 1989) to 30 percent.

As Table 2 shows, these changes and the sharp drop in the inflation rate meant a considerable leveling of the playing field across various types of owners and sources

5 In the United States, the top marginal federal tax rate was reduced to 28 percent. The marginal tax rate had peaked at 91 percent in the early 1960s (Slemrod and Bakija (2008)). 
Table 2: Effective marginal tax rates for different combinations of owners and sources of finance, 1991, 1994, and 2005 (10 percent real pretax rate of return at actual inflation rates).

\begin{tabular}{|c|c|c|c|}
\hline & Debt & New share issues & Retained earnings \\
\hline \multicolumn{4}{|l|}{1991} \\
\hline Households & 31.7 & 61.8 & 54.2 \\
\hline Tax-exempt institutions & -9.4 & 4.0 & 18.7 \\
\hline Insurance companies & 14.4 & 33.3 & 31.6 \\
\hline \multicolumn{4}{|l|}{1994} \\
\hline Households* & 32.0 & 28.3 & 36.5 \\
\hline Tax-exempt institutions & -14.9 & 21.8 & 21.8 \\
\hline Insurance companies & 0.7 & 32.3 & 33.8 \\
\hline \multicolumn{4}{|l|}{2005} \\
\hline Households* & 27.9 & 58.1 & 42.7 \\
\hline Tax-exempt institutions & -1.2 & 23.2 & 23.1 \\
\hline Insurance companies & 18.2 & 44.6 & 42.6 \\
\hline
\end{tabular}

of finance. During one single year, 1994, double taxation of dividends was abolished and the capital gains tax was lowered to 12.5 percent. In 1995, some differences based on type of owner and source of finance were reinstituted, although the discrepancies were now far smaller than they were before the tax reform.

The new tax system went a long way toward neutrality. However, the effective tax rate remained significantly higher for individual business ownership than for other owner categories and higher for individual business owners in most comparable countries OECD (1994).

\section{The Intellectual Underpinnings of the Increased Taxation of Individual Firm Ownership}

The belief that large-scale production and a collectivist social order fostered economic development had become influential in Sweden by the 1940s. Ernst Wigforss, Minister of Finance from 1925 to 1926 and again from 1932 to 1949 , was arguably the most influential of all SocialDemocratic ideologues and a strong advocate for this doctrine. In his writings, he argued that the dynamics of capitalism inevitably lead to progressively larger firms and production units. As a corollary, the individual entrepreneur and business owner simultaneously wanes in importance. The ultimate vision espoused by Wigforss (1952) consisted of an economy made up of "social enterprises without owners." ${ }^{6}$ He could even claim support from Schumpeter (1942), who in his later writings argued that the declining economic importance of the entrepreneur was a major force in the transformation from capitalism to socialism and that the innovation process would become more and more automated and routinized as a result of modern techniques and modern modes of organization. Innovations would no longer be connected with the efforts and brilliance of a single person. Instead, innovations were increasingly to become the fruits of the organized efforts of large teams within the framework of large corporations.

Among the influential policymakers during the first post-war decades, there was a strong belief in both the need for and the efficiency of economic planning. An increasing role for the state appeared to be both inevitable and desirable. Many observers, including the first Nobel Laureate in economics, Jan Tinbergen (1961), hypothesized that Eastern and Western economies would converge and eventually meet at a point at which the degree of socialism and state control in Western economies had progressed considerably from where they stood in the early 1960s. Over the same period, the state bureaucracies in the

6 In Swedish: "samhällsföretag utan ägare.” 
Eastern Bloc were expected to become more flexible and political oppression mitigated. In many circles, Sweden was understood as the Western forerunner toward such Tinbergen-type convergence.

Another contemporaneous social scientist who inspired policymakers at the time was Harvard professor John Kenneth Galbraith and, in particular, his books The Concept of Countervailing Power (1956) and The New Industrial State (1967), which provided a rationale for an economic policy geared toward the large corporation.

Galbraith argued that both innovations and improvements to existing products and production processes would occur most efficiently within large industrial corporations, while individual initiatives and individual incentives were becoming less and less important. Galbraith famously captured this view as follows (Galbraith (1956, p. 86)):

There is no more pleasant fiction than that technological change is the product of the matchless ingenuity of the small man forced by competition to employ his wits to better his neighbor. Unhappily, it is a fiction.

Undeniably, the Swedish Social-Democrats came to consider small firms and individual entrepreneurs as increasingly marginal agents in the development process. In fact, Anna Hedborg and Rudolf Meidner, the main architects behind the (blue-collar worker) Trade Union Confederation's (LO) wage-earner fund proposal, ${ }^{7}$ simply asserted that self-employment and small firms were of little economic importance (Hedborg and Meidner (1984)).

The notion of the economic system promulgated by Tinbergen, Galbraith, and many other social scientists at the time meshed well with the Social-Democratic ambition to achieve a highly equalized income and wealth distribution. In their comprehensive analysis of the trade union movement in the postwar period, Johansson and Magnusson (1998, p. 121) conclude that

the idea of a "capitalism without capitalists" becomes the glue that holds together collectivism and the dynamics of the market economy. In this way, capitalism can be rehabilitated, but at the same time there is no room for strong owners or capitalists. It then becomes possible to combine income equalization with high profits in the most dynamic firms. ${ }^{8}$

7 Meidner et al. (1975) and Meidner (1978).

8 In Swedish: “... blir idén om en 'kapitalism utan kapitalister' annars till det sammanhållande kittet mellan kollektivismen och marknadens dynamik. På detta sätt kan kapitalismen äreräddas - samtidigt som det inte finns plats för starka ägare eller kaptialister. Inkomstutjämning kan ske samtidigt som de mest dynamiska företagen tillåts göra stora vinster.”
A key tool in reaching this goal was to design the tax system in a manner that fostered this development. The political radicalization that gained momentum in Sweden in the late 1960s drastically changed the perception of capital income, facilitating such tax changes. More and more people considered capital income as morally questionable and even reprehensible.

In 1970, the journalist Gustaf Olivecrona, one of the most highly profiled journalists at the time, published his book De nya miljonärerna (The New Millionaires). Olivecrona describes the background, activities, and life styles of a number of entrepreneurs, including the florist entrepreneur Bengt Nygren and (by now) forgotten entrepreneurs such as Göte Borgström (the sports fishing equipment firm ABU), Arne Sandberg (the gas station chain Uno-X), and Elis Lindén (Lindénkranar).

Although Nygren had created Europe's largest vertically integrated flower company, his personal wealth was estimated to be a mere SEK 10 million (roughly SEK 80 million in today's prices). Nygren was vehemently attacked by the then-chairman of the Social-Democratic youth movement (SSU) Bosse Ringholm (Swedish Minister of Finance 1999-2004), who branded Nygren as "asocial and a danger to society." ${ }^{9} \mathrm{He}$ did this regardless of the fact that Nygren's innovations and entrepreneurship had turned what was previously a luxury good into a product that ordinary workers could afford. ${ }^{10}$

One conclusion drawn by left-leaning opinion leaders and activists was that Nygren should not be blamed for having created his fortune within the confines of Swedish legislation. Instead, the attack should be launched against the institutional framework that engendered-or even fostered-the accumulation of such wealth rather than against those law-abiding individuals who benefitted from the system. In the words of one editorial in the SocialDemocratic daily Aftonbladet: "Ringholm should realize that society is flawed, since it allows people to make millions. To condemn specific individuals is petty bourgeois. Read Marx, Bosse Ringholm!"11

\footnotetext{
9 In Swedish: “asocial och samhällsfarlig.” Quoted from Jörnmark (2007, p. 68).

10 Olivecrona (1970, p. 138). In Nygren's own words: “The money I have made is a trifle compared to the money that consumers earn on my ideas that I have put into practice because of my own pursuit of economic gain” Jörnmark (2007, p. 68; my translation).

11 In Swedish: "Ringholm borde inse att det är samhället det är fel på. Samhället tillåter nämligen folk att tjäna miljoner Det är småborgerligt att fördöma enskilda individer. Läs Marx; Bosse Ringholm.” Quoted from Jörnmark (2007, p. 68)
} 
This hostile attitude toward entrepreneurs could be and was justified, either implicitly or explicitly, by the Marxist theory of value, which maintained that all economic value is created by labor. As capital income typically emanates either from return on financial instruments or from return on ownership shares in firms, a person receiving such income was understood to be unduly profiting from the fruits of somebody else's labor.

Until the mid-1970s, it was possible to have strong development in the Swedish corporate sector in spite of the fact that no new business fortunes were created in the industrial sector and that existing ownership groups did not increase their wealth in real terms. It appeared feasible to combine strong economic development and a tax system that de facto barred the emergence of new individually owned entrepreneurial firms. Over time, the old industrial families were phased out and ownership and control in the Swedish business sector grew more and more concentrated (Glete (1994)). In other words, the vision of "capitalism without capitalists" appeared to be practically realizable. $^{12}$

Against the background of this history, it becomes easier to understand that leading Social Democrats began to believe that the time was ripe for taking yet another step; if the market economy could thrive without "wealthy capitalists," it could arguably continue to deliver increased prosperity even without capitalists. The stage was set for the wage-earner funds, cogently summarized in the now classic front-page heading of LO-Tidningen (the weekly paper of the Swedish Trade Union Confederation, LO) from 1978: "With the funds we take over, gradually." 13

\section{Swedish Taxation of Individual Firm Ownership in the Early 1970s}

To fully grasp how high the effective taxation on individual firm ownership was in the 1970s, it may be useful to look at a concrete example. Assume a 1973 firm with a net worth (equity) of SEK 10 million, ${ }^{14}$ a real rate of return on equity

12 Through dual-class shares (A and B shares with different voting power, sometimes resulting in a discrepancy of 1000:1), pyramiding, and cross or circular ownership, it was possible to control very large firms even though the capital bases of the controlling owners shrank relative to the total assets of the firms they controlled (Högfeldt (2005); Henrekson and Jakobsson (2001, 2012)).

13 LO-Tidningen, No. 6, 1978. In Swedish: "Med fonderna tar vi över successivt."

$14 € 1 \approx$ SEK 9.50 in early 2017. of 10 percent and in which the entire profit was paid as a dividend to the owner. I will later make a comparison with a firm of equal size some 40 years later.

In 1973, the corporate tax rate was 52 percent and the dividend tax was roughly 75 percent (the same tax rate as for labor income-in fact, 75 percent is probably on the low side as the top marginal tax rate was 78 percent and this rate applied to all income exceeding 4.4 times the average annual wage of a production worker). In addition, a wealth tax of at least 1.2 percent of the net worth of the firm was levied (I assume that the reduction rule that halved the statutory wealth tax rate was applicable). Table 3 shows that total payments as a share of nominal return amounted to 95 percent, whereas it amounted to 162 percent of real return.

The calculations indicate that the tax system made it well-nigh impossible to be an individual entrepreneur/business owner in Sweden in the 1970s. However, there were certain safety valves. Most obviously, firms could be extremely leveraged and pursue business activities that were eligible for various types of subsidies. The few individual fortunes that were created during this period, some of which remain intact, were with few (if any) exceptions created in the construction and real-estate sectors, including John Mattson, Einar Mattsson, Adam Backström, Jan Pehrson, and Lars Gullstedt. Many of them are forgotten, but in the 1970s, they were wealthy and famous real-estate tycoons ("fastighetsklippare").

Until 1973, there was an additional safety valve because business owners could borrow funds (even at zero interest rates) from their own firms to finance private consumption. This activity was disallowed in 1973 when it became illegal for shareholders and their family members to borrow from their own firms on any terms unless granted an exemption by the tax authorities (SOU 1998:116).

Moreover, although the dividend tax was very high, the capital gains tax was very low. In fact, the capital gains tax on long-term holdings (more than five years) was zero until 1966. Over the 1967-1975 period, only 10 percent of the sales proceeds were taxable (at the labor income tax rate). From 1976 until 1990, only 40 percent of capital gains were taxable if the shares had been held for at least two years.

As a result, a highly tax-efficient way to finance private consumption until 1973 was to borrow at zero interest rate from one's own firm, occasionally sell off part of the firm and then use the sales proceeds (tax-free or at a low capital gains rate) to repay the debt. People were even allowed to sell the firm to a newly formed company that only they owned. The Bonnier family did exactly this no less than four times (Larsson (2001)). Ingvar Kamprad borrowed large sums from IKEA in the 1950s and 1960s both 
Table 3: Effective owner-level taxation in 1973 for a firm having equity of SEK 10 million and a 10 percent real rate of return before tax when all profit accrues to the owner in the form of dividends.

\begin{tabular}{lc}
\hline & SEK \\
\hline Net worth/equity of firm & $10,000,000$ \\
Nominal return on equity & $1,700,000$ \\
Real return on equity before tax & $1,000,000$ \\
Corporate tax (52 percent) & 884,000 \\
Dividend to owner & 816,000 \\
Dividend tax (75 percent) & 612,000 \\
Dividend after tax & 204,000 \\
(Wealth tax on the net worth of the firm) & 240,000 \\
Wealth tax when reduction rule applicable & 120,000 \\
(Total tax payments, full wealth tax & $1,736,000)$ \\
Total tax payments, reduced wealth tax & $1,616,000$ \\
Total tax payments as a share of nominal return & 95.1 percent \\
Total tax payments as a share of real return & 161.6 percent \\
\hline
\end{tabular}

Note: Inflation rate is 7 percent; wealth tax $=2.5$ percent on wealth exceeding SEK 1 million and SEK 15,000 on the first million. There was also a rule that total tax payments should not exceed 85 percent of taxable income, although the wealth tax could never be reduced by more than 50 percent.

Source: The relevant tax rates are taken from Henrekson and Stenkula (2015).

to finance private consumption and to buy tax-favored life insurance policies that were purchased to finance the expected future payments of inheritance tax (Torekull (2011, p. 133)).

The most well-known (and controversial) businessman who systematically used this strategy was the entrepreneur Per-Olof Ahl, the founder of the clothing retail chain Kapp-Ahl (now KappAhl) (Olivecrona (1970)). He was a fixture in the tabloids during these years, boasting about his shrewdness and showing off his extravagant lifestyle.

Hence, an entrepreneur/business owner who sold off his firm enjoyed favorable tax treatment in the mid-1970s. By contrast, the individual entrepreneur who continued to own and operate his business paid prohibitively high taxes. The combination of a very low tax rate for those who chose to discontinue their ownership and the high effective taxation of those who remained in business had the expected impact.

There were two main types of prospective buyers for the medium-sized and large family-owned businesses. The first type of buyer consisted of larger incumbent firms, which thereby often evolved into disparate conglomerates (Volvo and Asea are prime examples). The second type of buyer consisted of listed investment companies, which were tax-favored; the first half of the 1960s, therefore, saw a second wave in which such companies were formed. ${ }^{15}$ They all had close ties to a specific bank, which was a necessity for ready access to debt financing, the most taxadvantaged source of financing, in the tightly regulated credit markets of the day. In 1971, there were as many as 19 investment companies listed on the Stockholm Stock Exchange (Lindgren (1994)).

\section{Tax-Driven Emigration and the Effects of Abstaining from Tax Planning}

A great many entrepreneurs sold their firms to investment companies or to other large firms and emigrated. Lindkvist (1990) reports that 30,000 Swedes who emigrated in the 1965-1989 period were granted permission by the Swedish central bank (the Riksbank) to export capital from Sweden. Many of these emigrants were entrepreneurs who had sold their companies, paid zero or low capital gains tax, and then moved to Switzerland or some other country in which wealthy immigrants were taxed lightly.

15 In a detailed analysis of six investment companies, Petersson (2001) documents a total of 111 acquisitions of mostly medium-sized family-owned firms in the 1962-1989 period. In some cases, large firms were acquired; 19 of the acquisitions were firms with more than 500 employees. 
However, some entrepreneurs still did not relinquish their vision of building a large firm and thus continued to develop their businesses. Several of the most successful entrepreneurs chose to emigrate and then continued to grow their firms from a non-Swedish base. The founder of Tetra Pak, Ruben Rausing, emigrated in 1969, and his two sons, Hans and Gad, emigrated in 1982. Two other spectacular examples are IKEA founder Ingvar Kamprad and H\&M founder Erling Persson. These entrepreneurs emigrated in 1973 and 1982, respectively, to escape Swedish taxation during critical phases in their firms' development. A more recent example is Fredrik Lundberg, who lived in Switzerland between 1985 and $1993 .{ }^{16}$

One successful entrepreneur who at first did not emigrate was the above-mentioned Bengt Nygren, founder of Buketten ("The Bouquet"). By 1967, Buketten had become Europe's largest floral retail chain and Europe's largest horticultural company. In the early 1970s, Buketten featured more than 100 outlets and its turnover was one-half that of H\&M.

In 1978, Nygren was solicited to collaborate with an American company to establish 1,000 flower shops in France and Germany. However, the Riksbank did not authorize Nygren to transfer the cash required to finalize the investment. He then sold Buketten and left Sweden for the United Kingdom. Five years later, Buketten filed for bankruptcy. Steep taxation combined with highly restrictive foreign exchange controls (which were in effect until 1989) made it virtually impossible for Nygren to accumulate the resources necessary to expand outside Sweden, despite his superior production technology and superior business model. ${ }^{17}$

Ingvar Kamprad and Erling Persson avoided Nygren's fatal mistake of trying to expand internationally from an ownership base domiciled in Sweden. Instead, Kamprad and Persson each emigrated at a critical phase in the development of their firms. Emigration allowed them to avoid harsh owner-level taxation and to be free of stringent foreign exchange controls.

Inheritance and gift taxes were also extremely high in Sweden at this time. In practice, these taxes were so high that the intergenerational transfer of large corporate wealth was impracticable. From the late 1940s until the mid-1970s, if the owner of a large firm died and the firm was

16 Wealthy entrepreneurs could emigrate and not be liable to pay tax in Sweden but still own and operate businesses in the country, as long as they did not spend more than 182 days per year in Sweden. 17 For more on Nygren, see Olivecrona (1970) and Nygren and Ericson (2011). inherited by two descendants, the inheritance tax alone invariably exceeded 50 percent of the net assets of the firm. ${ }^{18}$ The Johnson, Wallenberg, Söderberg, and Dunker families were forced to transfer their ownership to tax-exempt foundations to prevent their wealth from gradually eroding because of high effective taxation and/or to avoid the crippling burden of an inheritance tax on the order of 70 percent of the value of the net assets.

For a wealthy person who had not taken any action to mitigate the inheritance tax, this tax could become confiscatory. The most spectacular case is the estate of Sally Kistner. She was the widow of Erik Kistner, the pharmacist who-with financial backing from Stockholms Enskilda Bank (which was controlled by the Wallenberg family)became the sole owner of Astra, the pharmaceutical company (now AstraZeneca), in 1924 (Sundling (2003)). At the time of her death, Kistner was Astra's largest shareholder and the market value of her shares was roughly SEK 300 million. The inheritance tax was based on the market value on the date of death, and inheritance tax was also levied on the latent capital gains tax that resulted when the heirs were forced to sell Astra stock to pay the inheritance tax. The capital gains tax was almost 26 percent ${ }^{19}$ and the highest inheritance tax rate of 65 percent applied. Hence, the combined inheritance and capital gains tax amounted to approximately 90 percent, but before the shares could be liquidated, the stock market crashed and the Kistner estate had to file for bankruptcy because the tax payments due exceeded the total amount received from the sale of the shares (Tulin (1984)).

When Fredrik Lundberg-now one of Sweden's most powerful controlling owners-emigrated to Switzerland in 1985, he referenced the Kistner case. In an interview that year, he said: "As far as I am concerned the generational transfer is completed, but although I am only 33 years old I may end up being struck by a falling brick or die in a traffic accident. Should that be the case, the result would be a

18 An illustrative example is provided by Kjell-Olof Feldt (2012) in his biography of Axel Ax:son Johnson (1910-1988), the owner of the Johnson steel and trading conglomerate, one of Sweden's three largest industrial groups at the time. Feldt shows how the sharp increase in inheritance taxation in 1948 had a drastic effect on strategic decisions in the group.

19 Under the tax law, 40 percent of the capital gains were taxed at the marginal income tax rate of 80 percent and the acquisition cost could be set to 20 percent of the sales value. Thus, the capital gains tax equaled $0.4 \times(1-0.2) \times 0.8=25.6$ percent. 
Sally Kistner effect of an unrivalled magnitude in the history of Swedish business life." 20

For a person who lived in a rented apartment, had no loans, did not actively search for tax deductions, and earned a high taxable income, the tax rate in a particular year might exceed 100 percent. The most publicized example was Astrid Lindgren, the renowned author of several famous children's fiction books and a revered public persona, whose average tax rate for one year was 102 percent. The main reason that Lindgren had an average tax rate above 100 percent was related to the fact that mandatory social security contributions on business income could not be deducted until the following year. Hence, a large increase in business income led to a spike in the tax rate, which was reversed the following year. After discovering that her tax rate was 102 percent, she wrote the allegory "Pomperipossa i Monismanien," 21 which was published in Expressen, then Sweden's largest and most widely circulated newspaper. The allegory was published some six months before the 1976 general election. Few voters ever learned of the real explanation for Lindgren's high tax rate for the year in question. Instead, her case was used by the opposition parties as an emblematic representation of a tax system that they believed had become both economically oppressive and illegitimate. According to some observers, the Lindgren case contributed to the electoral loss that ended 44 years of virtually uninterrupted reign by the Social Democrats.

\section{The First Alleviations, Increased Tax Avoidance, and New Wealthy Capitalists}

The international discussion and the increasingly salient distortionary effects paved the way for a more open and pragmatic discussion across partisan lines regarding the perversions of the Swedish tax system. The tax code ne-

20 Cited from Engman (2013), who in turn cites an interview with Lundberg in the Swedish weekly business magazine Veckans Affärer from 1985 (my translation).

21 Pomperipossa is a mean and wealthy witch in a well-known Swedish fairy tale from 1896, written by Axel Wallengren, also known as Falstaff Fakir. Monismanien refers to the Swedish movie Monismanien 1995 (directed by Kenne Fant) that premiered the year before Lindgren's fairy tale was published. The movie portrays a future oneparty totalitarian country and what happens to a teacher who teaches his pupils to think independently. cessitated both strict foreign exchange controls and quantitative regulation of credit markets that prevented people from procuring large tax-deductible interest rate payments.

During the second half of the 1970s, the first modest deregulatory steps were taken. In 1978, the taxable net worth of unlisted firms was reduced to 30 percent for purposes of gifts, inheritance, which made intergenerational ownership transfer of large- and medium-sized family firms less costly, and substantially reduced the wealth tax on family firms. ${ }^{22}$ The intergenerational transfer was facilitated even further if (part of) the assets consisted of highly leveraged real estate with a tax-assessed value considerably below market value. ${ }^{23}$

The possibility of eliminating or greatly reducing the wealth and inheritance tax increased substantially following the credit market deregulation in the mid-1980s and was accomplished by acquiring highly leveraged assets with a tax-assessed value below market value, such as condominiums and art objects. Throughout the 1980s, the business press was filled with articles describing various strategies exploiting such tax breaks. An additional source highlighting the importance of such considerations for business behavior is provided by von Platen (1995), who interviews 14 successful entrepreneurs and reports that many of them complain that they had to enter into business deals primarily to reduce their tax burden and at the cost of increased financial risk and diminished focus on their core business.

Over time, loopholes and safety valves increased in both number and significance. In parallel with financial market deregulation, the opportunities grew for persons with high before-tax incomes to expand their balance sheets by means of debt financing. As interest payments were fully deductible, large loans allowed highincome earners to reduce their tax rate to very low levels and even become non-taxpayers ("nolltaxerare"). Someone who happened to have exceptionally high income in a single year was allowed to pay interest on a loan several years in advance, and the loan was then used to finance investment in assets in which capital gains were taxed at a low or zero rate (zero-coupon bonds, art objects, race

22 Some reduction of the wealth tax on ownership shares in unlisted firms was instituted already in 1974 when the tax authorities allowed a greater undervaluation of firms' stock-in-trade and inventories (Du Rietz and Henrekson (2015)).

23 A further advantage for this case was that it reduced or perhaps eliminated wealth tax payments. 
horses, long-term [> two years] holdings of listed stock, etc.)

As tax and credit market policies had strongly disfavored entrepreneurship and private wealth formation during the entire post-war period, corporate assets were exceptionally undervalued. The companies listed on the Stockholm Stock Exchange had never been valued lower relative to their assets and profitability. Tobin's $q$ (the market value of a firm's assets relative to replacement cost) was approximately 30 percent and price-to-earnings ratios typically hovered between 2 and 4 (Södersten (1984); Henrekson and Jakobsson (2001)).

The excessively low valuations of companies listed on the Stockholm Stock Exchange contributed to making the later rise in the stock market index more drastic than in the leading OECD countries. During the1980s, the Swedish stock market index grew almost three times more than the Dow Jones index, and if the time period is extended to include the 1990s, the Swedish stock market index rose almost five times more than the Dow Jones index. Thus, between January 1980 and January 2000, there was a 56fold increase in the Stockholm Stock Exchange index (including reinvested dividends) (Henrekson and Jakobsson (2012)).

This exceptional revaluation implied that a person who happened to have a modest stock market portfolio in the late 1970s came into a minor fortune just by holding on to those assets. For more active financial market investors, the combination of risk-taking, skill, and luck sometimes resulted in truly extraordinary rates of return. Therefore, despite the very high tax rates, many new family fortunes were created during the 1980s. By the end of this decade, there were several new wealthy capitalists who were primed to take a leading role in restructuring and renewing the Swedish business sector. These names include Gustaf Douglas, Ulf G. Lindén, Fredrik Lundberg, Anders Wall, Robert Weil, and Peo and Gerhard Lindholm (Sundqvist (1989)). These new private fortunes provided an important basis for the exercise of ownership control of large Swedish firms.

\section{Changing Views on the Determinants of Growth and Social Welfare}

During the 1980s, the so-called endogenous theories of economic growth were developed (Romer (1990); Lucas (1988)). Under these theories, investment in new knowl- edge is the most important source of growth. More recent research shows that investments in education and research and development (R\&D) must be complemented with the right incentives for entrepreneurship, competition, and mobility to translate into substantial economic growth (Braunerhjelm (2012)). Thus, institutional framework conditions, including informal institutions such as norms and practices, which shape incentives for economic agents, have a key role in determining the extent to which new knowledge leads to increased production of highly valued goods and services.

In a dynamic economy, products, firms, and entire markets continually disappear and are replaced by new products and new and more innovative and efficient firms. Markets are not only areas for mutually beneficial exchange but also arenas for experimentation in which new products, business models, and distribution methods are tested (Mantzavinos (2001)).

More radical innovations frequently emanate from smaller firms (Baumol (2010)). These firms, particularly the successful ones, are frequently spinoffs from large firms (Klepper (2016)). Thus, new technology is often developed, implemented, commercialized, and widely disseminated by new entrepreneurial firms. Acquiring new firms is also a way for leading firms to gain access to new technology.

The most important factor behind job dynamics is not firm size but firm age (Coad et al. (2014); Haltiwanger et al. (2017)). ${ }^{24}$ Entrepreneurship transforms new knowledge into innovations and business activity. Entrepreneurs create additional capital by combining knowledge, labor, human capital, and physical capital in novel ways.

In recent decades, an evolutionary approach to understanding economic growth has been developed as an alternative to endogenous growth models. ${ }^{25}$ This approach emphasizes the roles played by experimentation, diversity, variety, and selection, placing the spotlight on the importance of the environment and of opportunities for individuals and firms to exploit new and existing knowledge. The research on the role of innovation and entrepreneurship leads to the following conclusions regarding the appropriate design of the tax system: ${ }^{26}$

24 This also holds true for Sweden in recent years (Andersson et al. (2016)).

25 Nelson and Winter (1982) pioneered this approach. See Nelson (2008) for a survey of the literature.

26 See Henrekson and Sanandaji (2016) and Elert et al. (2017) for indepth discussions. 
- Owner-level taxation should treat all types of owners equally.

- Labor income taxes should not dampen individuals' incentives to invest in human capital and to its subsequent use.

- Taxes should not prevent key employees and entrepreneurs from obtaining a fair stake in the substantial capital value that materializes when a successful firm is developed, even if they lack financial resources of their own.

- The tax burden should be reasonably neutral with respect to the firm's size, age, industry, and financing structure.

- No wealth tax should be levied on corporate assets.

- Dividend and capital gains taxes should be low. In particular, it is important that the capital gains tax is low on long-term holdings.

\section{The Taxation of Entrepreneurship and Business Ownership in the 2010s}

The 1990/1991 tax reform dramatically changed the principles of the tax system by lowering tax rates, broadening tax bases, and making the system much simpler and more transparent. The most significant change was the sharp reduction of the tax rate on current capital income, which was reduced to 30 percent after hovering around 75 percent just a few years earlier. However, taxation of labor income remained high with a total tax wedge of some 65 percent, even at moderate income levels.

To offset the incentives for business owners to lower their effective tax rate by redefining more highly taxed labor income as capital income, a source model in which business income is split into income from capital and income from labor is applied. These rules, commonly known as the 3:12 rules, apply to closely held firms. A closely held firm is defined as an incorporated business with no more than four active owners controlling more than 50 percent of the common voting rights. Initially, these rules severely constrained such firms from paying dividends to the active owners, taxed at the capital income rate of 30 percent. For someone who had founded a firm based on the minimum equity requirement, the room for paying dividends taxed at 30 percent was negligible. Moreover, the capital gains tax was 40 percent ( 43 percent after 1995) instead of 30 percent, as half of the capital gains were taxed as labor income.
A number of changes in owner-level taxation have been enacted since the 1990/1991 tax reform, most of which have reduced the effective taxation of owners of closely held firms: ${ }^{27}$

- The wealth tax on assets in the form of unlisted shares was abolished in 1991.

- The wealth tax on controlling owners of listed firms was abolished in 1997.

- The gift and inheritance tax was repealed in 2004 and the wealth tax was repealed in its entirety in 2007. One way to mitigate or eliminate these taxes was to accumulate wealth in the form of ownership of unlisted firms. When these two taxes were repealed, this push effect into entrepreneurship and equity investment in unlisted firms vanished.

- The corporate tax rate has been reduced three more times; since 2013, it has been 22 percent.

- A series of changes in the rules for closely held firms have been implemented, which substantially expand the share of the owners' income that may be taxed as capital income.

The last point is the most important one. The successive reforms of the 3:12 rules have sharply increased the room for business income to be classified as capital income, which is now taxed at a rate of 20 percent as opposed to the standard rate of 30 percent. First, regardless of the size of the firm, the owner can always pay a dividend taxed at 20 percent of 2.75 income base amounts (SEK 163,075 in 2017), based on the so-called simplification rule.

If the owner does not use this option, low-tax dividends can be paid based on the sum of an imputed rate of return on the acquisition cost of the shares equal to the government bond rate plus 9 percentage points plus the so-called wage base allowance. To use the wage base allowance, the owner must receive a monthly wage of SEK 47,400. In that case, the owner(s) can pay total dividends based on the wage base allowance amounting to 50 percent of the total wage bill of the firm (but the total low-tax dividend payouts cannot exceed 50 times the annual wage of the owner).

These rules have created substantial room for paying low-tax dividends to owners of large- and medium-sized closely held firms. For example, in such a firm with a total wage bill of SEK 20 million, the owner can pay dividends of up to SEK 10 million taxed at 20 percent even when the

27 See Johansson et al. (2017) for an in-depth discussion and analysis of the many detailed changes in the 3:12 rules from their enactment in 1991 until 2016. 
Table 4: Effective owner-level taxation in 2015 for a firm having equity of SEK 60 million and a 10 percent real rate of return before tax when all profit accrues to the owner in the form of dividends.

\begin{tabular}{lc}
\hline & SEK \\
\hline Net worth/equity of firm & $60,000,000$ \\
Nominal return on equity & $6,000,000$ \\
Real return on equity before tax & $6,000,000$ \\
Corporate tax (22 percent) & $1,320,000$ \\
Dividend to owner & $4,680,000$ \\
Dividend tax (20 percent) & 936,000 \\
Dividend after tax & $3,720,000$ \\
Wealth tax on the net worth of the firm & 0 \\
Total tax payments & $2,256,000$ \\
Total tax payments as a share of real return & 37.6 percent \\
\hline
\end{tabular}

Note: Inflation rate is 0 percent.

Source: The relevant tax rates are taken from Henrekson and Stenkula (2015).

firm's equity base is a mere SEK 50,000 (assuming that the firm has sufficient profits to pay this amount). Unused dividend allowances are carried forward and can be accumulated at an interest rate of the government bond rate plus 3 percentage points. ${ }^{28}$ For passive owners of unlisted shares, both the dividend and the capital gains tax rate is 25 percent.

I will now repeat the calculation of the tax burden that was performed in Table 3 for an equally large firm 42 years later. In 1973, we noted that a real rate of return of 10 percent before tax eventually turned into a sizable negative rate of return after all the taxes were accounted for. To be comparable in size, the 2015 firm requires equity of SEK 60 million. There was no inflation in 2015, and I assume (realistically) that the dividend payment does not exceed the dividend allowance. The calculation in Table 4 shows that the real tax rate is only 38.8 percent in 2015 compared to 161 percent in 1973.

\section{The Reformed Taxation of Holding Companies}

Effective beginning July 1, 2003, a seemingly minor change in the tax code was enacted, which is in fact a change that greatly affects the effective taxation of business ownership. The change in the tax code implies that no tax is levied on distributed profits to the parent company from ownership in other unlisted firms regardless of

28 Any saved dividend allowances can also be used to lower the capital gains tax to 20 percent. whether they can be considered part of the parent's business (näringsbetingade andelar). Capital gains on näringsbetingade andelar also became tax exempt. The tax exemption applies to all stock holdings in unlisted incorporated firms regardless of ownership share and to holdings of stock in listed firms as long as the holding company owns shares comprising at least 10 percent of the votes or 10 percent of the equity. ${ }^{29}$

The new tax code thus made it possible to avoid (or indefinitely postpone) owner-level taxation both for controlling owners of listed firms and for individuals with ownership shares in unlisted firms.

Tax will then only be paid on that part of the return that the owner requires for private consumption purposes. Typically, such withdrawals will be subject to a 25 percent tax. In other words, since 2003, owners of large firms and large private investors in unlisted firms-such as the startup sector-are subject only to a consumption tax and profits remain untaxed as long as they are not paid out of their holding company.

Table 5 presents a realistic example involving a natural person holding a control bloc in a large listed company. The market value of the control bloc is SEK 200 billion and the dividend ratio is 3 percent. In the table, I compare total effective taxation using the tax rates in 1973 and 2015, respectively. Under the 1973 rules, the sum of the

29 The new legislation also granted full tax exemption to listed investment companies (Investor, Latour, Industrivärden, etc.) for dividends and capital gains from firms in which they hold at least a 10 percent voting or equity share. Prior to 2003, an investment company was subject to a 1.5 percent annual tax on its market cap, unless its dividend payouts were as large as all dividends received plus the 1.5 tax on its market cap. 
Table 5: Effective owner-level taxation of individually owned listed stock with a market value of SEK 200 billion and a dividend ratio of 3 percent according to the 1973 and 2015 tax code.

\begin{tabular}{lcc}
\hline & 1973 & 2015 \\
\hline Market value of stock & 200 & 200 \\
Dividend & 6 & 6 \\
Dividend tax (78 percent in 1973; maximum 30 percent in 2015) & 4.7 & $0-1.8$ \\
Wealth tax (halved because of reduction rule) & 2.5 & 0 \\
Net & -1.2 & $4.2-6$ \\
Tax payments as a share of dividend payout (percent) & 120 & $0-30$
\end{tabular}

Note: If the shares were owned by a wholly owned holding company in 2015, no tax was levied on the dividends from the listed stock. For the part of dividends paid out to the owner, the tax rate is 30 percent if the portfolio company is listed; otherwise it is normally 20 or 25 percent. Source: The relevant tax rates are taken from Henrekson and Stenkula (2015).

Table 6: Inheritance taxation when deceased's own child inherits individually owned listed stock having a market value of SEK 200 billion according to the 1973, 1979, and 2015 tax code.

\begin{tabular}{lccc}
\hline & 1973 & 1979 & 2015 \\
\hline Inheritance tax (65 percent of market value on death date) & 130 & 130 & 0 \\
Capital gains tax (10 percent of sales if sold at market value on death date) & 7.8 & 27.84 & 0 \\
Capital gains tax on sales to pay inheritance plus capital gains tax & 11.0 & 50.2 & 0 \\
Total & 141.0 & 180.2 & 0 \\
\hline
\end{tabular}

Note: The capital gains tax in 1973 was 7.8 percent (10 percent of the sales value was taxed as labor income). The capital gains tax in 1979 was 27.84 percent ( 40 percent of the nominal gain was taxed as labor income at a rate of 87 percent; heirs were allowed to deduct 20 percent as a standard acquisition cost).

Source: The relevant tax rates are taken from Henrekson and Stenkula (2015).

wealth tax (levied on 100 percent of the market value but reduced by half under the reduction rule) and the dividend tax amounts to 120 percent of the total dividend. By contrast, in 2015, there is no wealth tax and the dividend tax cannot exceed 30 percent. In practice, the bloc holder will not own the share directly but via a wholly owned holding company and as long as the dividend payment from the listed company remains within the holding company, the tax rate is zero.

In Table 6, I calculate the tax consequences for the case in which the owner dies and his or her control bloc is inherited by his or her children. In 2015, there were no tax consequences because the inheritance tax was repealed in 2004. In 1973, the inheritance tax was 65 percent of the market value of the stock for descendants (72 percent for siblings). The direct inheritance tax would then have been SEK 130 billion plus the capital gains tax, which amounted to 11 billion as long as one realistically assumes that the heirs must sell stock to pay the inheritance tax. If the control bloc of shares is the predominant asset in the estate of the deceased, a 30 percent drop in the stock price before liquidation is sufficient to force the estate to file for bankruptcy. A calculation based on the 1979 tax code is also included in the table to illustrate the effect when effec- tive inheritance taxation peaked. Total capital gains plus inheritance tax payments in that year equaled 90 percent.

The calculations presented in Tables 5 and 6 clearly show that owner-level taxation was so high in the early 1970s that it was not possible to either build or maintain ownership control as a natural person in Sweden. Four decades later, the situation is completely reversed, and the scope for accumulating corporate wealth without incurring any taxes (except at the corporate level in the portfolio companies) is unrestricted. Moreover, corporate wealth can be passed on to the next generation at any time without any tax consequences.

\section{The Taxation of Entrepreneurial Effort}

A large part of the entrepreneurial function in firms is undertaken by employees without ownership in the firm, and a successful firm can rarely be built without highly competent specialists whose skills are likely to be scarce and highly valued. The return on those skills will then be taxed as labor income. Although marginal tax rates are substantially lower in Sweden in 2017 than they were at their peak 
in the late 1970s, they remain quite high. Already at a fairly modest wage level (about 1.7 times the average wage of a production worker), the marginal tax wedge reaches 67 percent. ${ }^{30}$

The taxation of labor income in Sweden has been very high since at least the early 1960s. Stock options are one potential means by which founders and key employees with limited personal wealth can obtain a personal stake in the capital value that cannot be created unless they participate. A well-designed stock option program may induce a founder-entrepreneur to act as if he or she remained as owner of the venture, and employee stock options are thus a way to induce key employees to act more entrepreneurially. ${ }^{31}$

Firms are allowed to grant stock options in Sweden, but for any gains to be taxed at the lower capital gains tax rate, the tax authorities attribute a market value to the options, which typically greatly exceeds their value to the grantee. In practice, stock options can hardly ever be used in the Swedish startup sector to incentivize owners, employees, or hired specialists. ${ }^{32}$ If stock options are granted at no cost to the grantee and if the receipt and future relation to exercise the options are tied to continued employment in the firm, any future gains will be taxed as labor income, and the firm will have to pay mandatory social security contributions as if the gain was a regular wage payment.

Given Swedish tax rules, it is thus frequently more advantageous to sell the firm in its entirety and exit from its management. However, this implies that external financiers and (co)owners no longer benefit from the founder's knowledge and engagement, and they may not be very efficient at incentivizing other specialists who have key competencies for the development of the venture. Moreover, the financiers cannot use staged financ-

30 It is the sum of the marginal tax and the mandatory social security contribution as a share of the wage including social contributions. The latter is 31.42 percent (in 2017) of the wage and above a fairly low threshold (1.3 average wage of a production worker); the contributions lead to no extra benefits and are thus a pure tax.

31 How stock options can be used to incentivize key agents involved in innovation-based entrepreneurial venturing is explained in Gompers and Lerner (2001) and Henrekson and Sanandaji (2016, 2017). Henrekson and Sanandaji (2014) also explain why the Swedish tax code only enables a tax-efficient use of stock options/warrants in the buyout sector and not in the venture capital sector.

32 In March 2016, a government commission proposed that a taxfavored employee stock option scheme should be introduced SOU 2016:23. In December 2016, the Swedish government sent a draft bill to the Council on Legislation (Lagrådet) where the enactment of a taxfavored employee stock option scheme is proposed. ing in which continued support is conditional on attaining successive milestones. Instead, the initial investment becomes much larger, which raises the required growth rate and absolute return.

\section{The Wealthiest Families in the Early 1960s and Today}

As we have already noted, corporate wealth owned and controlled by individuals and families became increasingly controversial in the 1960s and early 1970s, eventually translating into political demands for harsh taxation of individual firm ownership.

Political support for this degree of sharp taxation, bordering on confiscation, of individual firm ownership would have been difficult to muster unless it could be shown that the distribution of ownership and control of the Swedish business sector was extremely skewed (and unfair). The future leader of the Swedish Communist Party, C.-H. Hermansson, contributed significantly to establishing this position. In 1959, he published the book Koncentration och storföretag (Concentration and Large Firms), in which he highlighted various aspects of power and control in Swedish industry. This book and the question regarding whether control in the business sector was highly concentrated was hotly debated, leading the Social-Democratic government to empanel a government commission (Koncentrationsutredningen) for the purposes of investigating the extent to which power in Swedish industry was highly concentrated. In 1962, Hermansson published a second book, Monopol och storfinans (Monopoly and Financial Capitalism), in which he coined the expression "the fifteen families." According to Hermansson, the 15 families he identified in his book de facto controlled Swedish industry. This worldview was later confirmed by an expert report to the government commission on ownership concentration SOU 1968:7 that identified the major industrial families and estimated the size of their fortunes.

The 15 years that followed the boom caused by the Korean War are often understood as the golden years of the Swedish model, with unprecedented growth in GDP and real household income (Lindbeck (1997)). However, despite the sustained boom and the exceptional growth of the largest Swedish firms (Glete (1994)), even the largest private fortunes were fairly small at that time, both relative to the size of the total economy and compared to the largest fortunes half a century later. Table 7 lists the 15 wealthiest families in 1963/1964-basically the same families identified by Hermansson-and their wealth in SEK and relative 
Table 7: Sweden's wealthiest families in 1963/64 and Sweden's wealthiest persons and families in 2016, in billion SEK and as a share of GDP.

\begin{tabular}{|c|c|c|c|c|c|}
\hline $1963 / 1964$ & Billion SEK & $\begin{array}{l}\text { Percentage of } \\
\text { GDP }\end{array}$ & 2016 & Billion SEK & $\begin{array}{l}\text { Percentage of } \\
\text { GDP }\end{array}$ \\
\hline Fam. Broström & 0.165 & 0.180 & Ingvar Kamprad & 655 & 15.0 \\
\hline Fam. Bonnier & 0.130 & 0.141 & Stefan Persson & 208 & 4.8 \\
\hline Fam. Wallenberg & 0.125 & 0.136 & Hans Rausing & 102 & 2.3 \\
\hline Incl. foundations & 0.500 & 0.545 & Jörn Rausing & 57 & 1.3 \\
\hline Fam. Wehtje & 0.100 & 0.109 & Antonia Ax:son Johnson & 55 & 1.3 \\
\hline Fam. Söderberg & 0.095 & 0.104 & Melker Schörling & 55 & 1.3 \\
\hline Incl. foundations & 0.110 & 0.200 & Finn Rausing & 54 & 1.2 \\
\hline Fam. Åhlén & 0.080 & 0.087 & Kirsten Rausing & 54 & 1.2 \\
\hline Fam. Ax:son Johnson & 0.080 & 0.087 & Fredrik Paulsen & 53 & 1.2 \\
\hline Incl. foundations & 0.105 & 0.114 & Ane Uggla & 47 & 1.1 \\
\hline Fam. Kempe & 0.065 & 0.071 & Dan Sten Olsson & 45 & 1.0 \\
\hline Incl. foundations & 0.135 & 0.147 & Bertil Hult & 40 & 0.91 \\
\hline Fam. Edstrand & 0.065 & 0.071 & Fredrik Lundberg & 34 & 0.78 \\
\hline Fam. Bergengren & 0.050 & 0.054 & Carl Bennet & 24 & 0.55 \\
\hline Fam. Kockum & 0.040 & 0.044 & Liselott Tham & 22 & 0.50 \\
\hline Fam. Klingspor & 0.035 & 0.038 & Fam. Kamprad & 682 & 15.6 \\
\hline Fam. Mark/Carlander & 0.025 & 0.027 & Ruben Rausing's heirs & 274 & 6.3 \\
\hline Fam. Stenbeck & 0.010 & 0.011 & Erling Persson's heirs & 268 & 6.1 \\
\hline \multirow[t]{3}{*}{ Fam. Ericsson } & 0.010 & 0.011 & Fam. Olsson (Stena) & 82 & 1.9 \\
\hline & & & Fam. Lundberg & 56 & 1.3 \\
\hline & & & Fam. Douglas & 40 & 0.91 \\
\hline
\end{tabular}

Note: GDP 1963: SEK 91.77 billion; GDP 2016: SEK 4,379 billion.

Source: SOU 1968:7 and Veckans Affärer (2016).

to Swedish gross domestic product (GDP). The table also lists the 15 wealthiest persons and the six wealthiest families (including heirs to the original founder) in 2016 and the size of their fortunes.

The first observation is that there is hardly any overlap between the two lists, ${ }^{33}$ as the Johnson family is the only family represented on both lists. Second, the fortunes are far larger relative to the size of the economy in 2016 than 52 years earlier. The wealthiest family in 1963/1964 was the Gothenburg shipping family Broström, and their total

33 It should be emphasized that comparisons of personal wealth in 1963/1964 and 2016 should be made with some caution. The 1963/1964 estimates are based on tax-assessed values, whereas the 2016 values consist of informed guesses by a business magazine in which the methods used are not fully transparent. These differences are likely to lead to underestimated wealth in 1963/1964 and possibly to some overestimation of wealth in 2016. Moreover, there has been a general increase in aggregate private net wealth relative to GDP from roughly 2.5 in the early 1960s to roughly 4.5 in the 2010s (Waldenström (2017)), which is likely to have had an independent effect on the size of individual fortunes relative to GDP. wealth was estimated to be 0.18 percent of Sweden's GDP in 1963 and SEK 1.7 billion in today's prices. The Broström fortune relative to GDP was fairly modest. To see this point more clearly, this amount is less than half of the wealth relative to current GDP that Markus "Notch" Persson earned by building and then selling his computer game company Mojang to Microsoft in 2014. ${ }^{34}$

If family foundations are included, the Wallenberg family was the wealthiest, with a total wealth of SEK 0.5 billion or 0.54 percent of GDP, which can be compared with the size of the fortunes of Ingvar Kamprad and the Rausing family, the founders of IKEA and Tetra Pak, respectively. Kamprad's assessed wealth in 2016 corresponded to 15 percent of Swedish GDP and the total wealth of the heirs to Ruben Rausing corresponded to 6.3 percent of Swedish GDP. The total wealth of the heirs to H\&M founder Erling Persson amounted to roughly 6.1 percent of Swedish GDP.

34 Markus Persson is number 18 on Veckans Affärer's list of Swedish billionaires with an estimated wealth of SEK 17 billion in 2016. 
In addition, there are several persons and families with fortunes in the interval of 1-2 percent of Sweden's GDP.

At least until fairly recently, a commonly held belief in Sweden was that it was difficult to create a fortune and that large fortunes were, with few exceptions, based on "old money." However, there is little support for this belief. On the contrary, out of the 178 billionaires identified by the Swedish business magazine Veckans Affärer in 2016, a fair number have inherited their wealth (in many cases through transfers in vivo), but the majority of these fortunes were built on business activities that were started or took off after 1970. Only 11 of the 178 billionaires can have the roots of their fortunes traced back to before the postwar period, and only 2 out of the 10 (Antonia Ax:son Johnson and Ane Uggla) are among the richest on the list. ${ }^{35}$

Kamprad's, Rausing's, and Persson's innovative entrepreneurship are prime illustrations of the fact that successful entrepreneurs often become wealthy in the course of developing and growing their businesses. As shown by Henrekson and Sanandaji (2017), this is typical: A majority of the world's dollar billionaires, 58 percent, acquired their wealth by starting a business. A large part of the remainder consists of heirs who continue to be engaged in and control the family business.

Nevertheless, the overwhelming bulk of the value created accrues to consumers in one of two ways: (i) imitators entering the market, which leads to enhanced competition and lower prices, or (ii) the original entrepreneur lowers prices and/or increases quality to deter entry by competing firms. Nordhaus (2005) estimates that often more than 95 percent (his best estimate is 97.8 percent) of the value created eventually accrues to consumers in the form of lower prices, more variety, and higher quality.

\section{Shifting Views in Some Respects}

Toward the end of the 1970s, there was a marked change in the international view of the market versus the planned economy. In addition, the growing role of large corporations and the concomitant marginalization of new and small firms came to a halt. Across the globe, there was a renaissance involving entrepreneurship and the individ-

35 Of the other nine individuals, four belong to the Bonnier family, three to the Stenbeck family, and two to the Söderberg family. Ane Uggla is the daughter of Arnold Mærsk Mc-Kinney Møller, the founder of A.P. Møller-Mærsk A/S, Denmark’s largest company. ual entrepreneur. The nature of technological change enabled increased specialization and focus on the core business, which resulted in outsourcing and downsizing. The industry structure also shifted from manufacturing toward services, and the production units and firms tend to be smaller in the latter. With rising real incomes, individual demand shifts toward more differentiated and customized products. Genuinely new products and production methods necessitate new entrepreneurial firms, while extensive deregulation of product markets undermined the market power of large incumbent firms, leading to new business opportunities for entrepreneurs and small firms. ${ }^{36}$

The general public's acceptance of individual wealth has also changed drastically. Over time, large private fortunes have become less controversial. In contemporary Sweden, the large number of super-rich persons and families are seldom criticized and, in many cases, they are both admired and revered. In the annual polls of the most admired persons in Sweden conducted by the polling institute SIFO on behalf of the magazine Icakuriren, Ingvar Kamprad and Antonia Ax:son Johnson habitually figure in the top group. ${ }^{37}$ However, it seems that a necessary condition for gaining wide acceptance for one's wealth is that such wealth is attributable at least in part to the fact that the value of one's own assets has risen dramatically, which almost invariably means that one actively participates in the development of a firm as owner.

By contrast, it remains a contentious issue when wealthy business owners copiously remunerate their CEOs (and other key employees) whom they have employed to lead and make crucial judgmental decisions in the firms they own and control. The entrepreneurial function is thus delegated to the management team and ultimately to the CEO. Prima facie, it seems self-evident that when a firm has a controlling owner, it is entirely expected that this owner will make an ex ante agreement with the CEO and his/her management team regarding the ex post distribution of the future value that is expected to be created as a result of the entrepreneurial decisions made by the CEO and the management team. ${ }^{38}$ However, this has remained a far more contentious issue. Two examples may illustrate this point.

When Johan Malmquist became the CEO of Getinge in 1997, its market cap was SEK 4.4 billion. When he re-

36 See Acs (1999) for further substantiation.

37 See, for example, http://www.expressen.se/nyheter/de-ar-popu larast-i-sverige/ and http://www.dn.se/nyheter/sverige/sprakroroch-sjukampare-bland-de-mest-beundrade/ (accessed March 31, 2017).

38 For a thorough discussion and analysis arriving at the same conclusion, see Pacces (2013). 
signed in 2015, the market cap was SEK 43 billion. During Malmquist's time as CEO, the value of the Getinge shares owned by Carl Bennet (the controlling owner) increased in value from SEK 0.5 to 8 billion.

Ola Rollén became the CEO of Hexagon in 2000. During his term, Hexagon's market cap has increased from SEK 2 to SEK 139 billion (in April 2017), and the value of the controlling owner Melker Schörling's Hexagon shares have increased from a net value of close to zero to more than SEK 7 billion.

Malmquist and Rollén have consistently been among the highest paid CEOs of those firms listed on the Stockholm Stock Exchange. From time to time, this compensation has been criticized and called into question by journalists, politicians, and trade union leaders. LO, the Swedish Trade Union Confederation, even conducts an annual study in which it compares and criticizes the annual salaries of top CEOs relative to that of ordinary workers. ${ }^{39}$

Opinions are similar when it comes to the compensation of partners in buyout firms and the top executives they assign to their portfolio companies. Media, the general public, politicians, and the Swedish Tax Agency have questioned whether these categories should be entitled to declare any part of their share of the return as capital income. These questions are asked despite the fact that this categorization involves the share of the return that has been stipulated ex ante in a contract with passive institutional investors. This stance suggests that it is generally perceived as morally and economically justified that the shareholders alone are legitimately entitled to any increase in the capital value and that other agents who contribute equally crucial inputs to the value creation process-such as entrepreneurs and key specialists-but happen to lack the financial means to acquire a substantial ownership share should be perceived as largely substitutable wage earners.

Similarly, it remains a widely held view that the only real risk takers, and, therefore, the only legitimate residual claimants, are those who contribute financial resources to the venture. However, this view is conceptually misguided. Arguably, the greatest risk is taken by those persons who spend the most critical years of their careers and risk their human capital in new risky ventures with a high expected

39 See Bergström et al. (2016). They compare the relative incomes of the CEOs of the 50 largest firms in the Swedish business sector to the average annual wage of a full time production worker. They calculate that the total before-tax capital plus labor income of the top CEOs increased from roughly 10 to 50 times the annual wages of a production worker from 1980 to 2014. rate of return. Their opportunity cost tends to be high, and, for most of them, a lucrative and far safer career in a large incumbent firm is a realistic alternative. Alternatively, they could perhaps have opted to start a new firm from scratch, thereby obtaining a substantial ownership share despite negligible financial means. That is exactly the manner in which many of today's wealthiest firm owners generated their wealth, or they were fortunate in that they embarked on their career at a point in time when the valuation of corporate assets was extremely low.

The sharp reduction in the effective taxation of large holdings of corporate wealth-from prohibitive levels in the 1970s to the current consumption tax-is often justified by referring to external forces that are beyond the control of domestic policymakers. However, this is unlikely to be the full explanation. The taxation of other forms of saving has also been greatly reduced; with the introduction of the capital insurance scheme (2007) and the investment savings account (2012), low-tax savings vehicles have become available for everybody.

By contrast, the tax system does not acknowledge that financial capital is but one of several ingredients required to start and successfully develop a business venture such that it can reach its full potential. Entrepreneurship is the combination of a business idea, the entrepreneur's human capital, work effort, and reinvested (retained) capital in the firm during the sustained period in which the firm must expand and attain a leading position in its market niche. Entrepreneurial effort is thus one part of an inseparable bundle of inputs supplied by a specific individual. It is not possible to unambiguously determine which share of the return on this bundle of inputs that should be defined as labor and capital income, separately.

Establishing and developing an innovative startup is a difficult and highly complex task. It requires the cooperation of several key actors with complementary competencies subject to a high degree of uncertainty, which creates high transaction costs. Various contractual mechanisms and other practices to handle and mitigate the effects of these transaction costs have evolved in the United States, particularly in Silicon Valley. A central component in these transactions is the granting of stock options to entrepreneurs and key specialists. Well-designed stock option contracts lower the labor costs for key personnel and creates the long-term commitment necessary to maximize the likelihood of future success. Such contracts can also be used to reduce the power of founders if the company underperforms and give the entrepreneurs successively larger control rights and equity stakes if the firm performs well. 
Substantial talent and financial resources have been channeled to the Swedish buyout sector in recent years. The buyout sector has been instrumental in rejuvenating and restructuring the Swedish economy (Olsson and Tåg (2017)). In 2010, the Swedish Tax Agency questioned the tax-efficient incentive-based remuneration schemes that had been established practice in the Swedish buyout sector since the 1990s. In 2014, the Supreme Administrative Court ruled in favor of the buyout firms (Klackenberg (2015)), which implied that no tax was levied on carried interest paid out to a partner's holding company. However, this ruling did not close the case. The Tax Agency instead claimed that dividends paid out from such holding companies should be subject to the 3:12 rules, which would entail that a substantial part of these dividends be taxed at the labor income tax rate. ${ }^{40}$ The Administrative Court ruled in the Tax Agency's favor, and this ruling was upheld by the Administrative Court of Appeal in April 2017.

Although the taxation of corporate wealth has been substantially lowered, it remains difficult for persons lacking financial resources to found and grow a new firm. The marginal taxation of labor compensation remains high (a marginal tax wedge of 67-70 percent even at fairly low annual incomes), which makes it difficult to accumulate startup capital through salaried work. By contrast, tax rules are generous when it comes to savings in the form of supplementary employer-paid pension contributions. It is even possible to fully control how these savings are invested as long as one invests in securities listed on a stock exchange or in other financial products offered by financial institutions.

\section{Conclusions}

Large personal fortunes accumulated as a result of entrepreneurship and firm ownership were strongly criticized in the post-war period, and by the early 1970s, such fortunes were considered illegitimate by a large part of the population. A key component of Social-Democratic policy from the early 1930s onwards was to achieve a flat income and wealth distribution, a system of "capi-

40 If these initial court rulings are upheld, it would mean that all dividends paid out until the end of 2011 (dating back to 2006) will be retroactively taxed as labor income, virtually always at the top marginal rate. From 2012, the first 90 income base amounts (= SEK $5,535,000$ in 2017) in dividends will be taxed at the labor income rate and any exceeding amount will be taxed at the standard capital income tax rate of 30 percent. talism without capitalists" with the goal of approaching Ernst Wigforss' vision of "social enterprises without owners." A host of policy measures were instituted to impede private/individual wealth accumulation through entrepreneurship and ownership of growing firms. By the mid-1970s, the effective taxation of firm owners was so harsh that it had become effectively prohibitive, with the possible exception of business owners in construction and real estate.

During the 1960s and 1970s, many Swedish entrepreneurs and owners of family firms either closed their operations or sold their firms. Owners of mediumsized and large firms could often sell their firms to bank-connected investment companies controlled by taxfavored owners or to large industrial firms. The capital gains tax was zero or very low and these owners were granted permission to migrate with the sales proceeds and their other assets to a country that taxed wealthy immigrants leniently. Some of the wealthy emigrant entrepreneurs did not give up building their firms. People like Ingvar Kamprad, Erling Persson, Hans Rausing, and Fredrik Lundberg emigrated to do just that with full force and without being hampered by Sweden's high taxes.

Today, the Swedish situation is dramatically different. Stefan Persson and Fredrik Lundberg had returned to Sweden by the 1990s, and Ingvar Kamprad returned to Sweden in 2013. The return of these super-rich firm owners cannot be explained by sudden homesickness. There is a rational explanation. The taxation of certain types of assets is today highly favorable in Sweden. New ways to tax savings have lowered the effective taxation of financial instruments. Deregulation and repeals of taxes on wealth and real estate have also led to a steep appreciation of asset values.

The inheritance and gift taxes have been abolished, indicating that large fortunes now can be transferred across generations without tax consequences. The situation was dramatically different in the 1970s when the inheritance and gift taxation schemes combined with capital gains tax could amount to almost 80 percent of the estate of a deceased owner of a large firm. By contrast, the effective tax rate is substantially higher for someone who lends money to or owns shares in an unlisted firm, particularly if the person is also actively working at the firm in question.

To the extent that the dramatic changes in the taxation of capital and firm ownership reflect a change in the values of the electorate, it is clear that matters are dramatically different from that in the 1970s. Today's numerous and large private fortunes are of a different order of magnitude than the family fortunes in the early 1960s, and 
their existence is far less controversial and politically contested.

A lenient effective taxation of large fortunes is probably easier to maintain because the official Swedish wealth register was scrapped in 2007 when the wealth tax was abolished..$^{41}$ As there are no systematic data, the public discussion has largely petered out. Instead, the public discussion focuses on differences and changes in the distribution of annual taxable incomes, as these are measured and published annually, ${ }^{42}$ which might explain why it is deemed to be politically impracticable to lower what is among the highest marginal income tax rates in the OECD, while it has been possible to lower the taxation of certain forms of savings to one of the lowest levels among all western countries.

In 2017, Sweden's tax code greatly favors individuals who have sizable wealth, whereas it is difficult to accumulate wealth for an initially penniless person because of the high taxation of labor income and because of a uniquely high valuation of existing assets. Moreover, tax changes in recent years have reduced the taxation of capital income from marketized securities and fund products compared to savings in the form of loans to-or ownership of shares in-entrepreneurial firms. The effective tax rate is also frequently higher for a person who engages actively in the firm as a controlling owner, business angel, or minority coowner, in addition to investing financially.

The difference in the effective taxation of a large firm in the mid-2010s compared to the 1970s is astounding. If someone had claimed in the mid-1970s that Sweden would have 178 billionaires 40 years later and that it would be economically advantageous for a billionaire to move back again from Switzerland (including repatriating his/her entire fortune), that person would most likely have been written off as more or less mentally deranged.

But will the political acceptance of today's low effective taxation of large fortunes persist? If so, will the elec-

41 See Waldenström (2007) for a discussion. The former register remained problematic in that many assets, particularly assets held by the wealthiest persons, had no tax-assessed value. This included a zero valuation of unlisted corporate stock and a very low valuation of land, condominiums, and commercial real estate. New estimates by Lundberg and Waldenström (2017) show an increase in wealth inequality after 2007 by approximately one-fifth (measured as the Gini coefficient for net wealth in the adult population). Moreover, they estimate that the top decile in the wealth distribution owns roughly twothirds of total wealth, and the top percentile owns 21 percent (in 2012). 42 Swedish income distribution was the most equal in the entire OECD until the late 1980s. Since then, income inequality has risen substantially, but incomes are still among the most equal in the OECD (OECD (2015)). torate also demand lower taxes on labor income? Or, has the taxation of capital income, and particularly of the owners of large corporate wealth, become so low that the pendulum will swing back toward higher capital-based taxes? Two important lessons from the historical comparisons in this article are that changes in attitudes and policies can become much greater than expected and that one should refrain from overconfident assertions about how the future will play out in this area.

About the author: Magnus Henrekson is a professor and president of the Research Institute of Industrial Economics (IFN). Until 2009, he was Jacob Wallenberg Professor at the Department of Economics at the Stockholm School of Economics. Since the end of the 1990s, Magnus Henrekson's primary research field is entrepreneurship economics.

\section{References}

Acs, Zoltan J., ed. (1999), Are Small Firms Important? Their Role and Impact. Boston, MI: Kluwer Academic Publishers.

Agell, Jonas, Peter Englund, and Jan Södersten (1995), Incentives and Redistribution in the Welfare State: The Swedish Tax Reform. London: MacMillan.

Andersson, Fredrik, Fredrik Heyman, Pehr-Johan Norbäck, and Lars Persson (2016), “Large Scope Business Sector Reforms: Has the Swedish Business Sector Become More Entrepreneurial than the U.S. Business Sector?” IFN Working Paper No. 1147. Stockholm: Research Institute of Industrial Economics.

Baumol, William J. (2010), The Microtheory of Innovative Entrepreneurship. Princeton, NJ: Princeton University Press.

Bergman, Lars, Pontus Braunerhjelm, Stefan Fölster, Magnus Henrekson, and Ulf Jakobsson (1998), Företagaren i välfärdssamhället. Konjunkturrådets rapport 1998. Stockholm: SNS Förlag.

Bergström, Jeanette, Anna Almqvist, and Anders Eld (2016), Makteliten - klyftorna större än någonsin. En studie av inkomstutvecklingen för makteliten perioden 1950-2014 och en studie av vd:ars globala arbetsmarknad. Stockholm: Trade Union Confederation, LO.

Braunerhjelm, Pontus (2012), “Innovation and Growth.” In Martin Andersson, Börje Johansson, and Hans Lööf, eds., Innovation and Growth: From R\&D Strategies of Innovating Firms to Economy-Wide Technological Change. Oxford: Oxford University Press.

Coad, Alex, Sven-Olov Daunfeldt, Werner Hölzl, Dan Johansson, and Paul Nightingale (2014), "High-Growth Firms: Introduction to the Special Section." Industrial and Corporate Change 23(1), 91-112.

Du Rietz, Gunnar, and Magnus Henrekson (2015), "Swedish Wealth Taxation (1911-2007)." In Magnus Henrekson and Mikael Stenkula, eds., Swedish Taxation: Developments since 1862. New York, NY: Palgrave Macmillan.

Du Rietz, Gunnar, Dan Johansson, and Mikael Stenkula (2015), “Swedish Capital Income Taxation (1862-2013)." In Magnus Henrekson and Mikael Stenkula, eds., Swedish Taxation: Developments since 1862. New York, NY: Palgrave Macmillan. 
Elert, Niklas, Magnus Henrekson, and Mikael Stenkula (2017), Institutional Reform for Innovation and Entrepreneurship: An Agenda for Europe. New York, NY: Springer.

Engman, Pascal (2013), “Okända systrarna som ärver miljarder.” EXpressen, 23 November.

Feldt, Kjell-Olof (2012), Den blyge entreprenören: om bergsingenjör Axel Ax:son Johnson. Stockholm: Ekerlids.

Galbraith, John Kenneth (1956), American Capitalism: The Concept of Countervailing Power. Boston, MA: Houghton Mifflin.

Galbraith, John Kenneth (1967), The New Industrial State. London: Hamish Hamilton.

Glete, Jan (1994), Nätverk i näringslivet. Stockholm: SNS Förlag.

Gompers, Paul A., and Josh Lerner (2001), The Money of Invention: How Venture Capital Creates New Wealth. Cambridge, MA: Harvard University Press.

Haltiwanger, John, Ron Jarmin, Robert Kulick, and Javier Miranda (2017), "High Growth Young Firms: Contribution to Job, Output, and Productivity Growth.” In John Haltiwanger, Erik Hurst, Javier Miranda, and Antoinette Schoar, eds., Measuring Entrepreneurial Business: Current Knowledge and Challenges. NBER Studies in Income and Wealth. Chicago, IL: University of Chicago Press.

Hedborg, Anna, and Rudolf Meidner (1984), Folkhemsmodellen. Stockholm: Rabén \& Sjögren.

Henrekson, Magnus, and UIf Jakobsson (2001), "Where Schumpeter Was Nearly Right - The Swedish Model and Capitalism, Socialism and Democracy." Journal of Evolutionary Economics 11(3), 331358.

Henrekson, Magnus, and Ulf Jakobsson (2012), "The Swedish Corporate Control Model: Convergence, Persistence or Decline?" Corporate Governance: An International Review 20(2), 212-227.

Henrekson, Magnus, and Tino Sanandaji (2014), Företagandets förutsättningar - en ESO-rapport om den svenska ägarbeskattningen. Report 2014:3 to ESO. Stockholm: Ministry of Finance.

Henrekson, Magnus, and Tino Sanandaji (2016), "Owner-Level Taxation and Business Activity." Foundations and Trends in Entrepreneurship 12(1), 1-101.

Henrekson, Magnus, and Tino Sanandaji (2017), "Schumpeterian Entrepreneurship in Europe Compared to Other Industrialized Regions 2017." IFN Working Paper. Stockholm: Research Institute of Industrial Economics.

Henrekson, Magnus, and Mikael Stenkula, eds. (2015), Swedish Taxation: Developments since 1862. New York, NY: Palgrave Macmillan.

Hermansson, Carl-Henrik (1959), Koncentration och storföretag. Stockholm: Arbetarkulturs Förlag.

Hermansson, Carl-Henrik (1962), Monopol och storfinans. Stockholm: Arbetarkulturs Förlag.

Högfeldt, Peter (2005), "The History and Politics of Corporate Ownership in Sweden." In Randall K. Morck, ed., A History of Corporate Governance around the World: Family Business Groups to Professional Managers. Chicago, IL: University of Chicago Press.

Johansson, Anders L., and Lars Magnusson (1998), LO andra halvseklet. Fackföreningsrörelsen och samhället. Stockholm: Atlas.

Johansson, Dan, Mikael Stenkula, and Gunnar Du Rietz (2015), “Capital Income Taxation of Swedish Households, 1862-2010." Scandinavian Economic History Review 63(2), 154-177.

Johansson, Dan, Mikael Stenkula, and Niklas Wykman (2017), "Swedish Capital Income Taxation of Owners of Closely Held Corporations, 1862 to 2015.” Mimeo. Stockholm: Research Institute of Industrial Economics.
Jörnmark, Jan (2007), Övergivna platser. Lund: Historiska Media.

King, Mervyn A., and Don Fullerton, eds. (1984), The Taxation of Income from Capital: A Comparative Study of the United States, the United Kingdom, Sweden, and West Germany. Chicago, IL: University of Chicago Press.

Klackenberg, Karl (2015), “Skatteverket - dåliga förlorare eller rättsutvecklare? En studie rörande beskattning av carried interest i Sverige." Master Thesis in Law. Lund: Faculty of Law, Lund University.

Klepper, Steven (2016), Experimental Capitalism: The Nanoeconomics of American High-Tech Industries. Princeton, NJ: Princeton University Press.

Larsson, Mats (2001), Bonniers - en mediefamilj. Stockholm: Albert Bonniers Förlag.

Lindbeck, Assar (1997), “The Swedish Experiment.” Journal of Economic Literature 35(2), 1273-1319.

Lindgren, Astrid (1976), “Pomperipossa i Monismanien.” Expressen, 10 March.

Lindgren, Håkan (1994), Aktivt ägande. Investor under växlande konjunkturer. Stockholm: Institutet för ekonomisk-historisk forskning (EHF).

Lindkvist, Hans (1990), Kapitalemigration. Doctoral Dissertation. Stockholm: EFI, Stockholm School of Economics.

Lucas, Robert E. (1988), "On the Mechanics of Economic Development." Journal of Monetary Economics 22(1), 3-42.

Lundberg, Jacob, and Daniel Waldenström (2017), "Wealth Inequality in Sweden: What Can We Learn from Capitalized Income Tax Data?" Review of Income and Wealth, forthcoming.

Mantzavinos, Chrysostomos (2001), Individuals, Institutions, and Markets. Cambridge: Cambridge University Press.

Meidner, Rudolf (1978), Employee Investment Funds: An Approach to Collective Capital Formation. London: Allen \& Unwin.

Meidner, Rudolf, Anna Hedborg, and Gunnar Fond (1975), Löntagarfonder. Stockholm: Tiden.

Nelson, Richard R. (2008), "Economic Development from the Perspective of Evolutionary Economic Theory." Oxford Development Studies 36(1), 9-21.

Nelson, Richard R., and Sidney G. Winter (1982), An Evolutionary Theory of Economic Change. Cambridge: Cambridge University Press.

Nordhaus, William D. (2005), "Schumpeterian Profits and the Alchemist Fallacy" Yale Working Papers on Economic Applications and Policy No 6. New Haven, CT: Department of Economics, Yale University.

Norrman, Erik, and Charles E. McLure (1997), "Tax Policy in Sweden." In Richard B. Freeman, Robert Topel, and Birgitta Swedenborg, eds., The Welfare State in Transition. Reforming the Swedish model. Chicago IL: University of Chicago Press.

Nygren, Bengt, and Bengt Ericson (2011), Mitt grönskande liv: berättelsen om springpojken som blev Sveriges blomsterkung. Stockholm: Fischer \& Co.

OECD (1994), Taxation of Small Businesses. Paris: OECD.

OECD (2015), “OECD Income Inequality Data Update: Sweden (January 2015)." Paris: OECD.

Olivecrona, Gustaf (1970), De nya miljonärerna. Stockholm: Wahlström \& Widstrand.

Olsson, Martin, and Joacim Tåg (2017) "Private Equity, Layoffs, and Job Polarization." Journal of Labor Economics, forthcoming

Pacces, Alessio M. (2013), Rethinking Corporate Governance: The Law and Economics of Control Powers. New York: Routledge. 
Petersson, Tom (2001), "Promoting Entrepreneurship. Bank Connected Investment Development Companies in Sweden 19621990." In Magnus Henrekson, Mats Larsson, and Hans Sjögren, eds., Entrepreneurship in Business and Research. Essays in Honour of Håkan Lindgren. Stockholm: Probus Förlag and Institute for Research in Economic History at the Stockholm School of Economics.

Romer, Paul M. (1990), “Endogenous Technical Change.” Journal of Political Economy 98(5), S71-S102.

Schumpeter, Joseph A. (1942), Capitalism, Socialism and Democracy. New York: George Allen \& Unwin.

Slemrod, Joel, and Jon Bakija (2008), Taxing Ourselves. Cambridge, MA: MIT Press.

Södersten, Jan (1984), "Sweden.” In Mervyn A. King and Don Fullerton, eds., The Taxation of Income from Capital: A Comparative Study of the United States, the United Kingdom, Sweden, and West Germany. Chicago, IL: University of Chicago Press.

Södersten, Jan (1993), "Sweden." In Dale W. Jorgenson and Ralph Landau, eds., Tax Reform and the Cost of Capital: An International Comparison. Washington, D.C.: Brookings.

SOU 1968:7, Ägande och inflytande inom det privata näringslivet. Expert Report No. $\mathrm{V}$ to Koncentrationsutredningen. Stockholm: Allmänna Förlaget.

SOU 1998:116, Stoppreglerna: Betänkande av Stoppregelutredningen. Stockholm: Fritzes.
SOU 2016:23, Beskattning av incitamentsprogram. Betänkande av Utredningen om skatteregler för incitamentsprogram. Stockholm: Regeringskansliet and Wolters Kluwer.

Sundling, Sven (2003), Per Aspera ad Astra. Stockholm: Ekerlids. Sundqvist, Sven-Ivan (1989), Ägarna och Makten i Sveriges Börsföretag 1989. Stockholm: Dagens Nyheters Förlag.

Swedish National Audit Office (2010), Enhetlig beskattning? RiR 2010:11. Dnr 31-2009-0252. Stockholm: Riksrevisionen.

Tinbergen, Jan (1961), “Do Communist and Free Economies Show Converging Patterns?” Soviet Studies 12(2), 333-341.

Torekull, Bertil (2011), Historien om Ikea. Stockholm: Månpocket.

Tulin, Lars (1984), "249 mkr till staten - inte ett öre till hennes arvingar." Dagens Industri, 20 November, p. 7.

Veckans Affärer (2016), “178 svenskar värda 2076 miljarder.” No. 49, 8 December, 36-65.

von Platen, Margaret (1995), De framgångsrika familjerna - att skapa och bevara förmögenheter. Stockholm: Ekerlids.

Waldenström, Daniel (2007), "Bättre forskning utan förmögenhetsregister." Dagens Industri, 19 September.

Waldenström, Daniel (2017), "Wealth-Income Ratios in a Small, Developing Economy: Sweden, 1810-2014.” The Journal of Economic History 77(1), 285-313.

Wigforss, Ernst (1952), Socialism i vår tid. Stockholm: Tidens Förlag. 